\title{
Physicochemical Characterization and Brix in Jersey Cow Colostrum in Tropical Conditions
}

\author{
Emerson Gabriel dos Santos Oliveira Silva ${ }^{1}$, Katya Anaya ${ }^{2}$, Maria de Fátima Bezerra ${ }^{1}$, Luis Henrique Fernandes \\ Borba $^{1}$, Idiana de Macêdo Barbosa ${ }^{1}$, Juliana Paula Felipe de Oliveira ${ }^{3 *}$, Stela Antas Urbano ${ }^{1}$, Cláudia Souza Macêdo ${ }^{1}$, \\ Dorgival Morais de Lima Júnior ${ }^{4}$, Marco Antônio Sundfeld da Gama ${ }^{\mathbf{5}}$ and Adriano Henrique do Nascimento Rangel ${ }^{1}$ \\ ${ }^{1}$ Federal University of Rio Grande do Norte, Specialized Academic Unit in Agricultural Sciences, Macaíba, 59280000, Brazil \\ ${ }^{2}$ Federal University of Rio Grande do Norte, Faculty of Health Sciences of Trairi, Santa Cruz, 59200000, Brazil \\ ${ }^{3}$ Federal University of Campina Grande, Center of Health and Rural Technology, Patos, 58708110, Brazil \\ ${ }^{4}$ Federal University of Alagoas, Arapiraca, 57309005, Brazil \\ ${ }^{5}$ Brazilian Agricultural Research Corporation - Dairy Cattle, Juiz de Fora, 36038330, Brazil \\ *For correspondence: jupaula.oliv@yahoo.com.br \\ Received 30 January 2021; Accepted 27 March 2021; Published 10 June 2021
}

\begin{abstract}
The objective of this study was to evaluate the nutritional composition (fat, total protein, casein, defatted dry extract, total solids and vitamin A), refractometry and $\mathrm{pH}$ of Jersey cow colostrum and correlations between Brix degree and colostrum constituents. Colostrum samples were collected from Jersey cow in the fifth milking after calving. Samples were identified and refrigerated until analysis. Data were subjected to analysis of variance and a descriptive analysis, while differences between milk were compared by the Duncan's test $(P<0.05)$ using the SAS version 9.0 software program. Pearson correlations were then performed between Brix grade and bovine colostrum constituents. The fat, total protein, casein, total solid and Brix percentage of the colostrum gradually decreased from the first to the fifth milking, while the lactose content increased. Positive correlations were observed between Brix values and protein, casein, total solids and defatted dry extract contents, while lactose was negatively correlated. The rapid reduction in Brix means and protein concentrations after delivery demonstrates the importance of administer colostrum in the shortest period after birth. (C) 2021 Friends Science Publishers
\end{abstract}

Keywords: Colostrum quality; Nutritional composition; Newborn protection; Passive immunization; Refractometry; immunoglobulin

\section{Introduction}

The first food of a newborn mammal is known as colostrum. It is produced by the bovine mammary gland, beginning at the end of gestation and ending a few days after birth (Micinski et al. 2017). Colostrum is a food with high nutritional value, abundant in a series of compounds with antimicrobial activities, amino acids and growth factors, and is essential for developing the calf's immune system (Blum and Hammon 2000; Zándoki et al. 2006; Sobczuk-Szul et al. 2013). The solids composition of colostrum varies between $21-27 \%$, being higher than the $12-13 \%$ which is observed for milk (Jaster 2005), and is influenced by the age of the animal, parity, health, nutrition, management, and season, among other factors (Tsioulpas et al. 2007).

The absorption of maternal immunoglobulins through colostrum is essential for preventing disease and death of the calf, as calves are hypogammaglobulinemic at birth (Gulliksen et al. 2008). Offering colostrum to the newborn should occur as shortly as possible after delivery to ensure high quality of colostrum. These concentrations may decrease by up to $3.7 \%$ every h after delivery (Morin et al. 2010).

Proper passive immunization of the calf is essential until its immune system develops. Therefore, directly evaluating colostrum immunoglobulin $\mathrm{G} \quad(\mathrm{IgG})$ concentration on the farm is recommended (Morrill et al. 2015). However, few farms employ equipment for its evaluation (e.g., colostrometer and refractometer) (Vasseur et al. 2010; Santos and Bittar 2015; Drikik et al. 2018), although they understand the importance of caring for the quality of colostrum.

Immunoglobulin concentrations in bovine colostrum are influenced by the number of milkings after delivery, reducing the immunization efficiency of neonates (Gomes et al. 2011). Colostrum has a nutritional composition consisting of necessary fats and proteins for the development of the offspring, in addition to its immunological importance (Angulo et al. 2015; Pyo et al. 2020).

The objective of this study was to evaluate the 
nutritional composition (fat, total protein, casein, defatted dry extract, total solids and vitamin A), refractometry and potential of hydrogen $(\mathrm{pH})$ of Jersey cow colostrum and the correlations between Brix grade and colostrum constituents from the first to the fifth milking.

\section{Materials and Methods}

\section{Herd selection and sample collection}

We collected 225 colostrum samples between August 2018 and April 2019 from the first five milkings after calving of Jersey cows belonging to a commercial farm located in São Gonçalo do Amarante - Rio Grande do Norte, Brazil. The climate was classifed as Aw, tropical with a dry season (Köppen-Geiger). The average rainfall in the region during the trial period was approximately $1500 \mathrm{~mm}$ per year, an average temperature of $26^{\circ} \mathrm{C}$, and average relative humidity of $78.0 \%$, according to data obtained from a meteorological station installed on the farm. The experimental group consisted of 45 animals, 22 primiparous and 23 multiparous managed under a compost barn system.

Individual colostrum samples were obtained per cow, with the first collection performed one $\mathrm{h}$ after delivery and the others with a 12-h interval between milking. These samples were collected through mechanical milking and placed in $40 \mathrm{~mL}$ plastic bottles, then later stored in isothermal boxes at a temperature of $3^{\circ}$ to $7^{\circ} \mathrm{C}$ and sent to the University's Milk Quality Laboratory Federal of Rio Grande do Norte (LABOLEITE-UFRN).

\section{Physicochemical analysis}

Colostrum samples were subjected to analysis by infrared absorption in an instrument (Dairy Spec ${ }^{\circledR}$, Bentley Instruments Inc., Chaska Minnesota, United States of America) to determine the levels of fat, total protein, lactose, casein, total solids and defatted dry extract. The equipment was calibrated using uncorrected data obtained from standard colostrum samples of jersey cows sent with the equipment, and which were prepared using chemical methods. The colostrum $\mathrm{pH}$ was measured using a digital pH meter (Lucademia ${ }^{\circledR}$, model LUCA-2010, São Paulo, Brazil) calibrated according to the manufacturer's recommendations.

\section{Refractometry}

The refractometry analysis was performed using a portable optical sugar refractometer $\left(\mathrm{Kasvi}^{\circledR}{ }^{\circledR}\right.$, model K52-032, measuring range 0 to $32 \%$ Brix and minimum division $0.2 \%$ ) after calibration with distilled water, as recommended by the manufacturer. A drop of colostrum was placed over the refractometer prism with the sample at room temperature and homogenized, and then read through the monocular lens. The Brix result was obtained by separating the light area from the dark area formed on the equipment display after its perpendicular arrangement to light.

\section{Densitometry}

The IgG concentration estimation in first milking colostrum was performed by reading the specific gravity using a colostrometer. Approximately $250 \mathrm{~mL}$ of room temperature colostrum was transferred to a beaker to which the densimeter was transferred, thereby allowing excess colostrum to overflow through the beaker until the equipment floated. The colostrum density was estimated from the scale just above the unsubmerged part of the densimeter floating freely in the beaker (Fleenor and Stott 1980).

\section{Retinol extraction}

Retinol extraction in colostrum was performed using the method of Giuliano et al. (1992), with adaptations. First, 1 $\mathrm{mL}$ of colostrum was added to light-protected polypropylene tube, and the samples were weighed after homogenization.

Retinol concentration was determined by High Performance Liquid Chromatography (HPLC) on a Shimadzu LC-10 AD Chromatograph, coupled with a Shimadzu UV-VIS SPD-10A Detector and Shimadzu Cromatopac C-R6A Integrator with a C18 LC Shim-pack CLC-ODS (M) $4.6 \mathrm{~mm} \times 25 \mathrm{~cm}$ column. The mobile phase used was $100 \%$ methanol, with a flow rate of $1 \mathrm{~mL} / \mathrm{min}$.

Retinol identification and quantification in the samples were established by comparison with retention times and areas of the respective standards. The pattern concentration was confirmed by the specific extinction coefficient $(\varepsilon 1 \%$, $1 \mathrm{~cm}=1780$ ) in absolute ethanol and $325 \mathrm{~nm}$ wavelength (Nierenberg and Nann 1992).

\section{Statistical analysis}

Data were submitted to analysis of variance and a descriptive analysis, while the differences between milk were compared by the Duncan test $(P<0.05)$ using the Statistical Analysis System (SAS) version 9.0 software program. Also, Pearson correlations were performed between Brix grade and bovine colostrum constituents.

The general mathematical model used was: $\mathrm{y}_{\mathrm{ij}}=\mu+\mathrm{t}_{\mathrm{i}}$ $+\varepsilon_{\mathrm{ij}}$, in which: $\mathrm{y}_{\mathrm{ij}}=$ dependent variables (physicochemical constituents of milk); $\mu=$ overall mean; $t_{i}=$ effect of the $i^{\text {th }}$ treatment; $\varepsilon=$ residual effect.

\section{Results}

\section{Physicochemical composition of colostrum}

The results from evaluating the physicochemical components of Jersey cows' colostrum in its first milking after calving are shown in Table 1 . A difference $(P<0.05)$ 
for the fat percentage was observed among the evaluated milkings, with higher values found for the first milking $(5.78 \%)$ and lower values for the fifth milking $(2.97 \%)$.

The protein fraction of colostrum showed statistical differences among the evaluated milkings, with a rapid decrease in the values of the first milking $(22.63 \%)$ to the fifth $(6.72 \%)$.

Following the results verified for total protein, there was a reduction in colostrum casein $(P<0.05)$ with the advancing lactation, with values of $18.75 \%$ for the first milking and $5.67 \%$ for the fifth milking. There was a rapid decrease in its concentration between the first and third milking $(12.07 \%)$ with a decrease of $6.68 \%$.

In contrast to the other components, lactose presented lower concentration in the first milking (1.09\%) and gradually increased until the fifth $(2.48 \%)$.

Significant differences $(P<0.05)$ were observed for the total solids means among the evaluated milkings, with the first milking colostrum presenting the highest value $(31.33 \%)$, while the fifth milking colostrum presented the lowest (13.43\%).

No statistical differences $(P<0.05)$ were observed for vitamin A concentrations in the different milkings.

\section{Refractometry and pH in colostrum}

Brix values were gradually reduced from the first $(29.45 \%)$ to the fifth (13.94\%) milking (Table 2).

As can be seen in Fig. 1, strong positive correlations were found between Brix values and protein, casein, total solids and non-fat dry matter (NFDM).

\section{Discussion}

A difference $(P<0.05)$ for the fat percentage was observed among the evaluated milkings. Means for first milking near $5.3 \%$ for the fat percentage were observed by Morrill et al. (2012) for Jersey cows' colostrum.

The reduction in colostrum fat fraction with advancing lactation was also reported by El-Fattah et al. (2012) and Micinski et al. (2017); however, the latter found rates of $7.12 \%$ for the first milking and $5.90 \%$ for the third day of lactation, constituting higher values than those observed in the present study. Contarini et al. (2014) described increased concentration of fat levels with advancing lactation.

The protein fraction of colostrum showed statistical differences among the evaluated milkings, with a rapid decrease in the values of the first milking to the fifth. The protein values observed in the present study were higher than the $17.5 \%$ reported by Sobczuk-Szul et al. (2013) for protein in Jersey cows' colostrum in the first milking after calving. The means in the present study were also higher than the findings of Micinski et al. (2017), in which the authors reported concentrations of $15.13 \%$ in the first milking, $9.19 \%$ in the second milking, and $4.51 \%$ on the third day of lactation in confined Holstein colostrum. The high protein concentration in this period may related to the higher amount of casein and immunoglobulins (IgG, IgA and $\operatorname{IgM}$ ) in colostrum, as these immunoglobulins have the function of protecting the calf from diarrhea and other gastrointestinal diseases which represent more than $62 \%$ of mortality cases in newborns (Baumrucker et al. 2010; Oliveira et al. 2018).

A reduction in colostrum casein with the advancing lactation and a rapid decrease in its concentration between the first and third milking were also reported by Madsen et al. (2004). However, more detailed studies show that the different casein fractions may vary differently; in this sense, Sobczuk-Szul et al. (2013) reported increased $\alpha$-casein on the second day of lactation, reduced $\kappa$-casein and maintenance of constant $\beta$-casein during the colostral period.

The gradual increase in lactose confirms the behavior reported in studies conducted by Conte and Scarantino (2013) and El-Fattah et al. (2012) in analyzing the colostrum behavior in Dutch cows. El-Fattah et al. (2012) reported an increase in lactose values during lactation. In a study with confined Dutch cattle, Micinski et al. (2017) observed averages of $2.77 \%$ for lactose in the first milking after delivery, $3.57 \%$ for the second milking, and $3.94 \%$ for third day colostrum.

The low lactose values in colostrum are interesting for calf digestion, as their body has difficulty digesting sugars, causing animals to have diarrhea (Lang 2008). Unlike other colostrum components, lactose synthesis tends to increase over the course of lactation, and then stabilizes within 5 days after delivery (Nakamura et al. 2003). The viscous characteristic and low amount of colostrum water is related to its low lactose concentration, which according to Bleck et al. (2009), acts as an osmoregulatory agent, since its synthesis causes water transfer from the cytoplasm of mammary epithelial cell to the secretory vesicles and consequently to milk (Fox and Kelly 2006).

The significant reduction in total solids between the evaluated milkings reflects the gradual decrease over time for the fat, total protein and casein percentages, as reported by El-Fattah et al. (2012). In a study conducted by SobczukSzul et al. (2013) comparing colostrum samples from Jersey and Holstein cows, it was observed that total solids and defatted dry extract percentages in the first milking after calving were higher for Jersey animals, which obtained an average of $28.47 \%$ for total solids and $23.34 \%$ for defatted dry extract. In a similar study, Morrill et al. (2012) observed $23 \%$ values for total solids in Jersey cows' colostrum.

No statistical differences were observed for vitamin A concentrations in the different milkings; however, the values of 369.3 (IU/dL) for the first milking, 480.7 (IU/dL) for the second milking, and 488.8 (IU/dL) for the third milking observed in the present study were higher than the values of 250.0 (IU/dL), 270.83 (IU/dL) and 312.5 (IU/dL) for the colostrum of the first three milkings from Dutch cows (ElFattah et al. 2012). 
Table 1: Physicochemical composition of colostrum (mean \pm SD)

\begin{tabular}{llllllll}
\hline Milking & Fat $(\%)$ & Protein $(\%)$ & Casein $(\%)$ & Lactose $(\%)$ & Total solids $(\%)$ & Non-fat dry matter (\%) & Vitamin A (UI/dL) \\
\hline 1 & $5.78^{\mathrm{a}} \pm 0.51$ & $22.63^{\mathrm{a}} \pm 1.62$ & $18.75^{\mathrm{a}} \pm 1.37$ & $1.17^{\mathrm{c}} \pm 0.18$ & $31.33^{\mathrm{a}} \pm 1.88$ & $23.61^{\mathrm{a}} \pm 1,80$ & $369.3 \pm 333.91$ \\
2 & $2.85^{\mathrm{b}} \pm 0.51$ & $20.93^{\mathrm{a}} \pm 1.75$ & $16.64^{\mathrm{a}} \pm 1.39$ & $1.06^{\mathrm{c}} \pm 0.17$ & $25.67^{\mathrm{b}} \pm 1.77$ & $22.82^{\mathrm{a}} \pm 1.67$ & $480.7 \pm 07.97$ \\
3 & $4.05^{\mathrm{ab}} \pm 0.56$ & $15.20^{\mathrm{b}} \pm 1.28$ & $12.07^{\mathrm{b}} \pm 1.03$ & $1.48^{\mathrm{c}} \pm 0.27$ & $21.52^{\mathrm{bc}} \pm 1.79$ & $17.46^{\mathrm{b}} \pm 1.40$ & $488.8 \pm 35.78$ \\
4 & $3.37^{\mathrm{bc}} \pm 0.66$ & $10.91^{\mathrm{c}} \pm 1.10$ & $8.66^{\mathrm{bc}} \pm 0.88$ & $1.76^{\mathrm{bc}} \pm 0.41$ & $16.68 \mathrm{~cd} \pm 1.26$ & $13.29^{\mathrm{bc}} \pm 0.88$ & $268.2 \pm 06.46$ \\
5 & $2.97^{\mathrm{bc}} \pm 0.75$ & $6.72^{\mathrm{cd}} \pm 0.64$ & $5.67^{\mathrm{cd}} \pm 0.57$ & $2.48^{\mathrm{b}} \pm 0.38$ & $13.43^{\mathrm{d}} \pm 1.06$ & $10.39^{\mathrm{c}} \pm 0.43$ & $204.8 \pm 89.58$ \\
\hline
\end{tabular}

SD: Standard deviation. Averages with distinct letters in the same column differ from each other by the Duncan test $(P<0.05)$

Table 2: Brix (\%), pH values in Jersey cow colostrum $(\mathrm{x} \pm \mathrm{SD})$

\begin{tabular}{lllll}
\hline Milking & $1^{\text {st }}$ & $2^{\text {nd }}$ & $3^{\text {rd }}$ & $4^{\text {th }}$ \\
\hline Brix $(\%)$ & $29.45^{\mathrm{a}}{ }_{ \pm} 0.65$ & $26.19^{\mathrm{b}}{ }_{ \pm} 0.92$ & $20.28^{\mathrm{c}}{ }_{ \pm} 0.99$ & $16.16^{\mathrm{d}}{ }_{ \pm} 0.61$ \\
$\mathrm{pH}$ & $6.23^{\mathrm{a}}{ }_{ \pm} 0.19$ & $6.54^{\mathrm{a}}{ }_{ \pm} 0.14$ & $6.62^{\mathrm{a}}{ }_{ \pm} 0.09$ & $6.58^{\mathrm{a}}{ }_{ \pm} 0.09$ \\
\hline
\end{tabular}

$\mathrm{SD}=$ Standard deviation. Averages with distinct letters on the same line differ from each other by the Duncan test $(P<0.05)$

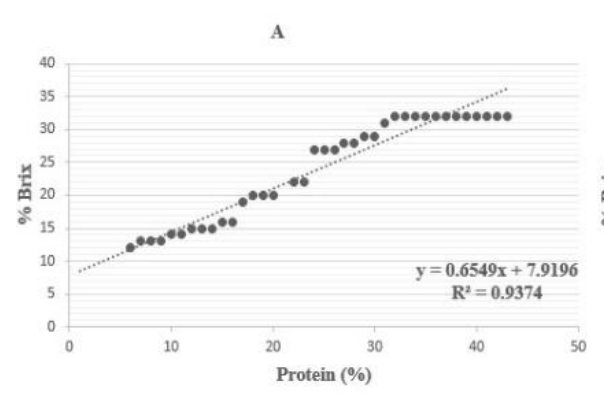

C
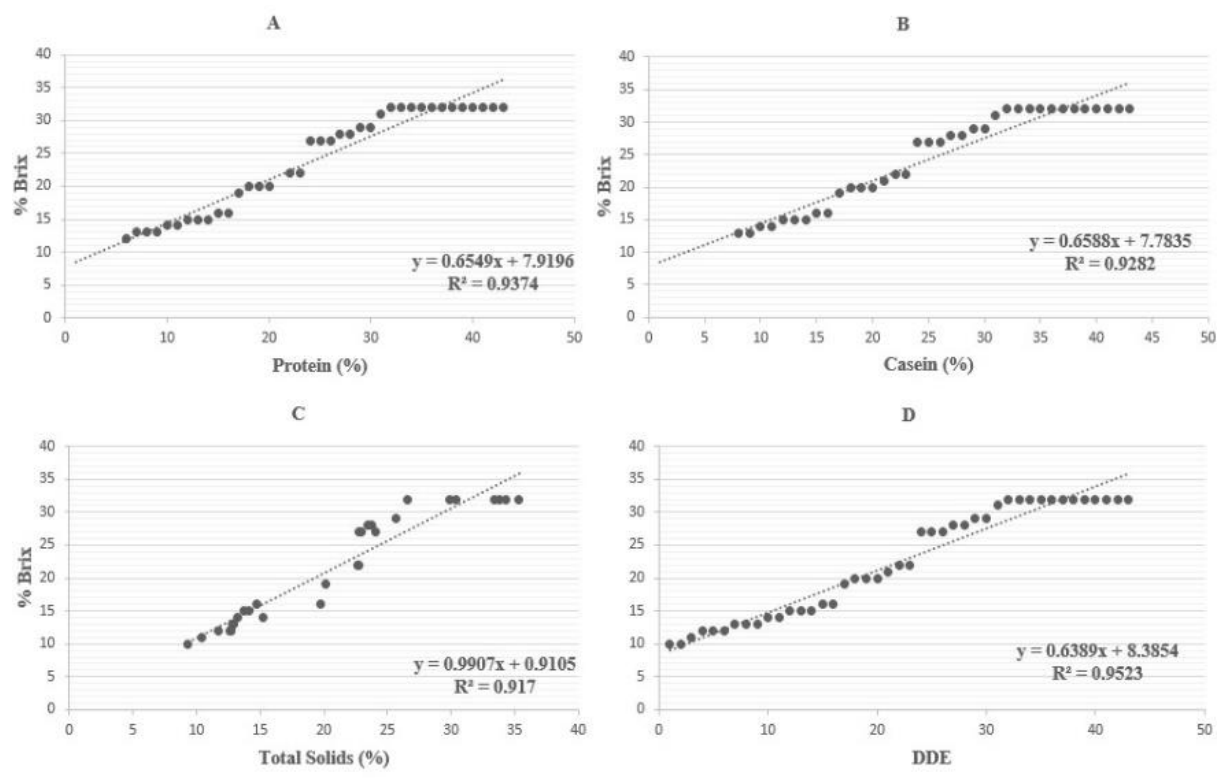

D
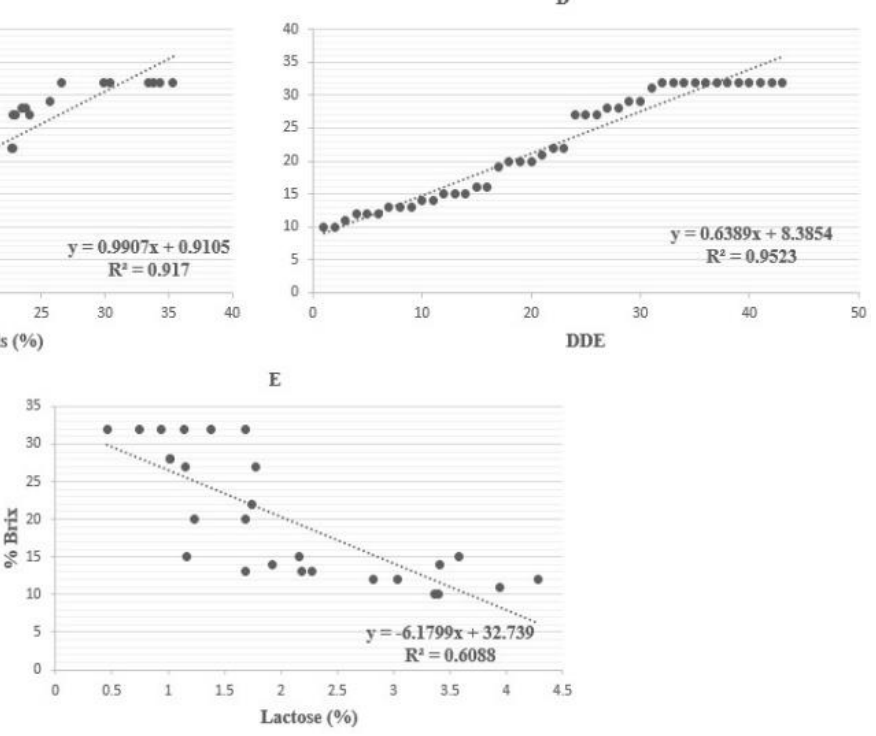

Fig. 1: Pearson correlations between Brix grade and bovine colostrum constituents: A) Protein; B) Casein; C) Total Solids; D) DDE; E) Lactose

In a study conducted by El-Fattah et al. (2012), as well as in the present study, we could observe an increase in vitamin A values in the second and third milking after birth, which follows an increasing behavior of these components at the beginning of the colostrum period, which may be related to the decrease in the immunoglobulin levels. As noted by El-Fattah et al. (2012), there was a decrease in these levels for the third day colostrum, in which the authors reported values of 159.63 (IU/dL), constituting lower values than the 203.5 (IU/dL) observed in the current study.
The $105.71 \pm 5,23(\mathrm{mg} / \mathrm{mL}) \mathrm{IgG}$ values for the density reading in the first milking colostrum observed in the present study are higher than the $84.49(\mathrm{mg} / \mathrm{mL})$ reported by Morril et al. (2015) for measuring IgG in fresh Jersey cow colostrum.

In a study aimed at evaluating the use of refractometer and colostrometer to determine colostrum quality, Bartier $e t$ al. (2015) reported that although the colostrometer overestimates IgG concentration, it can be used on farms, provided that a cut-off point of $80 \mathrm{mg} / \mathrm{mL}$ is employed. 
Colostrometer use is uncommon on farms, despite recommendations to do so. In order to know the management practices adopted in 174 dairy farms in the states of São Paulo, Minas Gerais and Paraná, Santos and Bittar (2015) observed that only $7.4 \%$ of the breeders are using a colostrometer or refractometer for evaluating colostrum quality.

The amount of immunoglobulins present in colostrum influences the newborn's immunization, so it is usually reduced during lactation as the animal develops its own immune system (Morrill et al. 2015). Thus, it is important that the producer has such knowledge to favor management which ensures an adequate colostrum supply to the newborn calf.

The immunoglobulin concentration may be represented by the light refraction obtained by Brix (Chavatte et al. 1998). Colostrum obtained shortly after delivery in the present study exceeds the mean Brix (21.24\%) reported by Morrill et al. (2015), and the average of $23.8 \%$ observed by Quigley et al. (2013). According to McGuirk and Collins (2004) and Silva-del-Río et al. (2017), high quality colostrum with values greater than $50 \mathrm{mg}$ $\mathrm{IgG} / \mathrm{mL}$ when refractionally evaluated has $21 \%$ Brix values.

Morrill et al. (2015) suggested the use of colostrum with values equal to or greater than $21 \%$ for Holstein cows and $18 \%$ for Jersey cows; thus, it can be sad that the values observed for the first $(29.45 \%)$, second $(26.19 \%)$ and third milking $(20.28 \%)$ in the present study meet the requirements of the IgG values for high quality Jersey colostrum.

Strong positive correlations were found between Brix values and protein, casein, total solids and non-fat dry matter (NFDM). According to Chavatte et al. (1998), a refractometer can capture the refraction of protein molecules (immunoglobulins and casein) in light, serving as an estimate for the amount of protein in colostrum, which influences the concentrations of total solids and NFDM.

Thus, the negative correlation between Brix and lactose in Fig. 1 (E) is due to the inverse behavior of lactose and the other colostrum constituents, with lactose being the only component which increased concentration during lactation until reaching mature milk values.

\section{Conclusion}

In conclusions, the fat, total protein, casein, total solids, NFDM, and the Brix percentage of colostrum gradually decreased from the first to the fifth milking, while the lactose content increased. Positive correlations were observed for Brix values and protein, casein, total solids and defatted dry extract contents and negative correlation with lactose. The rapid reduction in Brix means and protein concentrations after delivery demonstrates the importance of colostration offering in the shortest period possible after birth. The observed Brix values for the studied herd suggest that the colostrum of Jersey cows can be used for colostrum bank production up to the third milking.

\section{Acknowledgments}

We give thanks to the We give thanks to the Coordination for the Improvement of Higher Education Personnel (CAPES-Brazil) for financial support.

\section{Author contributions}

EGSOS and AHNR conceptualization, EGSOS, MFB, AHNR and SAU, methodology, EGSOS, IMB and MFB formal Analysis, EGSOS, IMB, MFB, JPFO, SAU, LHFB and DMLJ investigation, LHFB data curation, EGSOS writing - original draft preparation, EGSOS, JPFO, AHNR, SAU, MFB, CSM, DMLJ, MASG and KA writing - review \& editing, AHNR supervision. All authors have been involved in commenting on and reviewing the manuscript.

\section{Conflicts of Interest}

The authors declare that there are no conflicts of interest.

\section{Data Availability}

All the data related to this study is included in the article, further inquiries can be directed to the corresponding author.

\section{Ethics Approval}

The project which originated this study was submitted to the Animal Use Ethics Committee of Federal University of Rio Grande do Norte (CEUA-UFRN), being approved for legal implementation (protocol 098.023/2018), in accordance with Law No. 11,794, 2008.

\section{Funding Source}

This project received financial support from the Coordination for the Improvement of Higher Education Personnel (CAPES-Brazil)

\section{References}

Angulo J, LM Gómez, L Mahecha, E Mejía, J Henao, C Mesa (2015). Calf's sex, parity and the h of harvest after calving affect colostrum quality of dairy cows grazing under high tropical conditions. Trop Anim Health Prod 47:699-705

Bartier AL, MC Windeyer, L Doepe (2015). Evaluation of on-farm tools for colostrum quality measurement. J Dairy Sci 98:1878-1884

Baumrucker CR, AM Burkett, AL Magliaro-Macrina, DC Dechow (2010). Colostrogenesis: Mass transfer of immunoglobulin G1 into colostrum. J Dairy Sci 93:3031-3038

Bleck GT, MB Wheeler, LB Hansen, H Chester-Jones, DJ Miller (2009). Lactose synthase components in milk: Concentration of alphalactalbumin and beta 1, 4-galactotransferase in milk of cows from several breeds at various stages of lactation. Reprod Domest Anim 44:241-247

Blum JW, H Hammon (2000). Colostrum effects on the gastrointestinal tract, and on nutritional, endocrine and metabolic parameters in neonatal calves. Livest Prod Sci 66:151-159 
Chavatte P, F Clement, R Cash, JF Grognet (1998). Field determination of colostrum quality by using a novel, practical method. AAEP Proc 44:206-209

Contarini G, M Polovo, L Pelizzola, A Monti, L Bruni, F Passolungo, L Degano (2014). Bovine colostrum: Changes in lipid constituents in the first 5 days after parturition. J Dairy Sci 97:5065-5072

Conte F, S Scarantino (2013). A study on the quality of bovine colostrum: Physical, chemical and safety assessment. Intl Food Res J 20:925931

Drikik W, C Windeyer, S Olsen, Y Fu, L Doepel, J Buck (2018). Determining the $\operatorname{Ig} G$ concentrations in bovine colostrum and calf sera with a novel enzymatic assay. J Anim Sci Biotechnol 69:1-9

El-Fattah AMA, FHA Rabo, SM El-Diede, HA El-Kashef (2012). Changes in composition of colostrum of Egyptian buffaloes and Holstein cows. BMC Vet Res 8:8-19

Fleenor WA, GH Stott (1980). Hydrometer test for estimation of immunoglobulin concentration in bovine colostrum. J Dairy Sci 63:973-977

Fox PF, AL Kelly (2006). Indigenous enzymes in milk: Overview and historical aspects - part 1. Intl Dairy J 16:500-516

Giuliano AR, EM Neilson, BE Kelly, LM Canfield (1992). Simultaneous quantitation and separation of carotenoids and retinol in human milk by high performance liquid chromatography. Meth Enzymol 213:391-399

Gomes V, KM Madureira, S Soriano, AM Melville, PD Libera, MG Blagitz, FJ Benesi (2011). Factors affecting immunoglobulin concentration in colostrum of healthy Holstein cows immediately after delivery. Pesq Vet Bras 31:53-56

Gulliksen SM, KI Lie, L Solverod, O Osterås (2008). Risk factors associated with colostrum quality in Norwegian dairy cows. J Dairy Sci $91: 704-712$

Jaster EH (2005). Evaluation of quality, quantity, and timing of colostrum feeding on immunoglobulin g1 absorption in jersey calves. $J$ Dairy Sci 88:296-302

Lang B (2008). Colostrum for the Dairy Calf, Factsheet Order No. 08-001, Agdex 411/23 1-4. Accessed: May 21, 2020

Madsen BD, MD Rasmussen, MO Nielsen, L Wiking, LB Larsen (2004). Physical properties of mammary secretions in relation to chemical changes during transition from colostrum to milk. $J$ Dairy $S c i$ $71: 263-272$

McGuirk SM, M Collins. Managing the production, storage, and delivery of colostrum (2004). Vet Clin North Amer Food Anim Prac 20:593-603

Micinski J, J Pogorzelska, A Beisenov, I Aitzhanova, G Shaikamal, DD Kuźmińska, B Micínski (2017). Basic and mineral composition of colostrum from cows in different ages and calving. J Elem 22:259 269

Morin ED, SV Nelson, ED Reid, DW Nagy, PD Constable (2010). Effect of colostral volume, interval between calving and first milking, and photoperiod on colostral IgG concentrations in dairy cows. J Amer Vet Med Assoc 237:420-428
Morrill KM, KE Robertson, MM Spring, AL Robinson, HD Tyler (2015). Validating a refractometer to evaluate immunoglobulin G concentration in Jersey colostrum and the effect of multiple freezethaw cycles on evaluating colostrum quality. J Dairy Sci 98:595-601

Morrill KM, E Conrad, J Polo, A Lago, J Campbell, J Quigley, H Tyler (2012). Estimate of colostral immunoglobulin $\mathrm{G}$ concentration using refractometry without or with caprylic acid fractionation. J Dairy Sci 95:3987-3996

Nakamura T, H Kawase, K Kimura, Y Watanabe, M Ohtani, I Arai, T Urashima (2003). Concentrations of sialyloligosaccharides in bovine colostrum and milk during the prepartum and early lactation. J Dairy Sci 86:1315-1320

Nierenberg DW, SL Nann (1992). A method for determining concentrations of retinol, tocopherol, and five carotenoids in human plasma and tissue samples. Amer J Clin Nutr 56:417-426

Oliveira EGS, AHN Rangel, DC Sales, JS Bezerra, EPE Silva, YMO Silva, LHF Borba, DML Júnior (2018). Caracterização físico-química do colostro de búfalas na primeira ordenha pós-parto por meio de absorção infravermelha. Rev Bras Cienc Vet 25:31-35

Pyo J, K Hare, S Pletts, Y Inabu, D Haines, T Sugino, LL Guan, M Steele (2020). Feeding colostrum or a 1:1 colostrum: Milk mixture for 3 days postnatal increases small intestinal development and minimally influences plasma glucagon-like peptide- 2 and serum insulin-like growth factor-1 concentrations in Holstein bull calves. J Dairy Sci 103:4236-4251

Quigley JD, A Lago, C Chapman, P Erickson, J Polo (2013). Evaluation of the Brix refractometer to estimate immunoglobulin $\mathrm{G}$ concentration in bovine colostrum. J Dairy Sci $96: 1148-1155$

Santos G, CMM Bittar (2015). A survey of dairy calf management practices in some producing regions in Brazil. Rev Bras Zootec 44:361-370

Silva-del-Río N, D Rolle, A García-Muñoz, S Rodríguez-Jiménez, A Valldecabres, A Lago, A Pandey (2017). Colostrum immunoglobulin $\mathrm{G}$ concentration of multiparous Jersey cows at first and second milking is associated with parity, colostrum yield and time of first milking, and can be estimated with Brix refractometry. J Dairy Sci 100:5774-5781

Sobczuk-Szul M, Z Wielgoz-Groth, M Wronski, A Rzemieniewski (2013). Changes in the bioactive protein concentrations in the bovine colostrum of Jersey and Polish Holstein-Friesian cows. Turk J Vet Anim Sci 37:43-49

Tsioulpas A, AS Grandison, MJ Lewis (2007). Changes in physical properties of bovine milk from the colostrum period to early lactation. J Dairy Sci 90:5012-5017

Vasseur E, F Borderas, RE Cue, D Lefebvre, D Pellerin, J Rushen, KM Wade, AM Passillé (2010). A survey of dairy calf management practices in Canada that affect animal welfare. J Dairy Sci 93:13071316

Zándoki R, J Csapó, Z Csapó-Kiss, I Tábori, Z Domokos, E Szücs, J Tözsér (2006). Change of amino acid profile in Charolais cows' colostrum and transient milk during the first week post-partum. Czech J Anim Sci 51:375-382 